\title{
Zinc and copper levels in low birth weight deliveries in Medani Hospital, Sudan
}

\author{
Rihab M Abass ${ }^{1}$, Hamdan Z Hamdan²*, Elhassan M Elhassan, Sumia Z Hamdan², Naji I Alii and Ishag Adam
}

\begin{abstract}
Background: Low birth weight (LBW) is a worldwide health problem, especially in developing countries. We conducted a case-control study at Medani Hospital, Sudan. Cases were women who delivered a LBW $(<2500 \mathrm{~g})$ newborn and consecutive women who delivered a normal weight (>2500 g) newborn were controls. Questionnaires were used to collect clinical data. Zinc and copper levels were measured by an atomic absorption spectrophotometer.

Findings: The two groups (50 in each arm) were well matched in their basic characteristics. Median (25-75th interquartile range) maternal zinc (62.9 [36.3-96.8] vs. 96.2 [84.6-125.7] $\mu \mathrm{g} / \mathrm{dl} ; P<0.001)$ and copper (81.6 [23.7-167.5] vs. 139.8 [31.9-186.2] $\mathrm{\mu g} / \mathrm{dl} ; P=0.04$ ) levels were significantly lower in cases than in controls. Cord copper levels in cases were significantly lower than those in controls (108 [55.1-157.9] vs. 147.5 [84.5-185.2] $\mu \mathrm{g} / \mathrm{dl} ; P=0.02)$. There were significant direct correlations between birth weight and maternal copper levels and maternal and cord zinc levels.
\end{abstract}

Conclusions: Maternal zinc and copper levels, as well as cord copper levels, are lower in LBW newborns than in those with normal weight.

Keywords: Zinc, Copper, Low birth weight, Sudan

\section{Findings}

Low birth weight (LBW) is a major health problem in developing countries, especially in sub-Saharan Africa, including Sudan $[1,2]$. Birth weight is the main predictor of infant morbidity, survival, and health status [3]. LBW $(<2500 \mathrm{~g})$ has many adverse outcomes, such as increased susceptibility to adulthood diseases (e.g., coronary heart disease, diabetes mellitus, hypertension, and obstructive lung disease) $[4,5]$, and it is the leading cause of perinatal and infant mortality $[6,7]$.

Zinc and copper are important trace elements that are needed for optimum human growth and development [8]. Zinc and copper are cofactors in many antioxidants enzymes that protect the cell against free radicals $[9,10]$. Zinc is involved in normal metabolic and physiological processes that control cell growth [11]. Zinc requirements are increased during pregnancy [12]. Low levels of zinc and copper are independently associated with a risk of LBW neonates [13-15].

LBW is a common health problem in different regions of Sudan and maternal anemia is the main risk factor for

\footnotetext{
* Correspondence: hamdanology@hotmail.com

${ }^{2}$ Faculty of Medicine, Al-Neelain University, P.O. Box 12702, Khartoum, Sudan Full list of author information is available at the end of the article
}

LBW [2,16-18]. A high rate of zinc and copper deficiency has been reported among pregnant Sudanese women, regardless of their age and parity [19]. There are few published data on maternal and cord levels of zinc, copper, and LBW deliveries, with contradictory results [14,15,20-22] Therefore, these elements need to be investigated in LBW neonates to provide health planners and care-providers with fundamental data necessary for appropriate intervention. The current study was conducted at Medani Hospital to investigate maternal and cord blood levels of zinc and copper in LBW newborns.

\section{Methods}

A case-control study was conducted at Medani Maternity Hospital in Central Sudan during May to October 2010. Medani is the capital of Al Gezira state, which is the second largest state in Sudan. The state of Al Gezira has a surface area of $26,0752 \mathrm{~km}^{2}$ and 4.133 .048 inhabitants, which represent $11.1 \%$ of the total population of Sudan. According to World Bank data, the gross national income per capita in Sudan is $\$ 1500$. Sudan is a developing country with a low middle-income level and $46.5 \%$ of its population is below the poverty line [23]. Medani Maternity Hospital is a tertiary hospital in $\mathrm{Al}$ 
Gezira state, and this receives referral cases from different medical centers and patients who live close to the hospital. After signing an informed consent form, women with a singleton neonate were approached to participate in this study. Cases were women who delivered a term newborn weighing $\leq 2499$ g. For every case, a subsequent woman who delivered a term newborn weighing $\geq 2500$ g by normal vaginal delivery acted as a control. Cases and controls were women who used iron and folic acid supplement only and no any other supplements. Sociodemographic data were gathered using a structured questionnaire for each woman. The obstetrical history, including information on the first day of the last menstrual period before the index pregnancy and on the date of previous pregnancy outcomes (delivery and miscarriage), was gathered. The inter-pregnancy interval was defined as the time between the woman's previous delivery, miscarriage and the first day of the last menstrual period for the index pregnancy. The date of the last normal menstrual period was used to determine gestational age. However, when a discrepancy between gestational age determined in this way and gestational age calculated from ultrasound scanning was greater than 2 weeks, the ultrasound estimate was preferred. All women with diabetes mellitus, a hypertensive disorder of pregnancy, those who developed obstetrical complications, such as gestational diabetes and antepartum hemorrhage, or those who suffered from any medical illness were excluded. Maternal weight, height, and body mass index, which was calculated as weight in kilograms divided by height in meters squared, were obtained. Newborns were immediately weighed with an electronic digital scale to the nearest $50 \mathrm{~g}$.

Maternal hemoglobin was measured using the HemoCue hemoglobinometer (HemoCue AB, Angelhom, Sweden).

Maternal venous and cord blood was immediately collected after birth from each woman and allowed to clot in plain tubes. Serum was stored at $-20^{\circ} \mathrm{C}$ until later analysis in a laboratory in Khartoum for measurement of serum zinc and copper concentrations. Zinc and copper concentrations were measured by an atomic absorption spectrophotometer (SOLAAR, Atomic Absorption Spectrophotometer, Thermo Electron, Cambridge, UK).

\section{Statistical analysis}

Data were entered in a computer using SPSS for Windows version 16.0 and double-checked before analyses. Data were checked for normality. Data are shown as mean (SD) when normally distributed and median (25-75th interquartile range) when not normally distributed. To compare mean variables, the Student's $t$ test was used for normally distributed data and the Mann-Whitney $U$ test was used if data were not normally distributed. Pearson's correlation was used to assess the association of zinc and copper with clinical, biochemical, and obstetrical data, and the correlation between these clinical and biochemical data. $P<0.05$ was considered significant.

\section{Ethics}

This study received ethical clearance from the Research Board at the Faculty of Medicine, University of Khartoum, Sudan.

\section{Results}

The two groups (50 in each arm) were well-matched in their basic characteristics (Table 1). Maternal serum zinc (62.9 [36.3-96.8] vs. 96.2 [84.6-125.7] $\mu \mathrm{g} / \mathrm{dl} P<0.001)$ and copper (81.6 [23.7-167.5] vs. 139.8 [31.9-186.2] $\mu \mathrm{g} / \mathrm{dl}$; $P=0.04$ ) levels were significantly lower in cases with LBW deliveries than in controls. Similarly, cord copper levels were significantly lower in cases with LBW deliveries than in controls (108 [55.1-157.9] vs. 147.5 [84.5185.2] $\mu \mathrm{g} / \mathrm{dl} ; P=0.02)$. Cord zinc levels were lower in cases than in controls (87.1 [43.3-118.1] vs. 92.2 [65.0$114.5] \mu \mathrm{g} / \mathrm{dl} ; P=0.49)$, but this did not reach statistical significance (Table 2, Figures 1 and 2).

There were significant direct correlations between birth weight and maternal zinc levels $(r=0.27, P=0.005)$, and between birth weight and maternal copper levels $(r=0.19$, $P=0.05)$. Similarly, cord zinc levels were positively correlated with maternal zinc levels $(r=0.29, P=0.003)$ and birth weight $(r=0.35, P=0.01$, Table 3$)$.

\section{Discussion}

The main findings of the current study were that maternal zinc and copper levels were lower and cord copper levels were lower in LBW deliveries compared with controls. This could explain recent findings at the same hospital, where anemic women were at nine times the risk of LBW delivery [2] and 45\% of antenatal attendees had zinc deficiency [19]. The finding of a low zinc level in LBW deliveries is in agreement with recent reports from developing countries, such as Tanzania [14] and India [15]. Maternal zinc deficiency can lead to an adverse pregnancy outcome, such as intrauterine growth retardation

\begin{tabular}{|c|c|c|c|}
\hline Variable & $\begin{array}{l}\text { Controls } \\
(n=50)\end{array}$ & $\begin{array}{l}\text { Cases } \\
(n=50)\end{array}$ & $P$ value \\
\hline Age, years & $27.54(5.06)$ & $27.5(6.3)$ & 0.98 \\
\hline Parity & $2.04(1.5)$ & $2.1(2.3)$ & 0.80 \\
\hline Gestation age, weeks & $38.1(1.2)$ & $37.8(1.9)$ & 0.43 \\
\hline Inter-pregnancy interval, months & $22.5(16.7)$ & 16.6(17.7) & 0.09 \\
\hline Weight, kg & $65.02(14.3)$ & $59.9(12.7)$ & 0.06 \\
\hline Body mass index, $\mathrm{kg} / \mathrm{m}^{2}$ & 25.4(3.9) & $23.9(4.5)$ & 0.08 \\
\hline Hemoglobin, g/dl & $11.1(1.4)$ & $10.8(1.4)$ & 0.38 \\
\hline
\end{tabular}

Values are mean (SD). 
Table 2 Zinc and copper levels in maternal and cord blood

\begin{tabular}{lccc}
\hline Variable & Cases $(\boldsymbol{n}=\mathbf{5 0})$ & Control $(\boldsymbol{n}=\mathbf{5 0})$ & $\boldsymbol{P}$-value \\
\hline Maternal zinc & $62.9(36.3-96.8)$ & $96.2(84.6-125.7)$ & $<0.001$ \\
Cord zinc & $87.1(43.3-118.1)$ & $92.2(65.0-114.5)$ & 0.49 \\
$P$-value & 0.15 & 0.12 & \\
Maternal copper & $81.6(23.7-167.5)$ & $139.8(31.9-186.2)$ & 0.04 \\
Cord copper & $108(55.1-157.9)$ & $147.5(84.5-185.2)$ & 0.02 \\
$P$-value & 0.16 & 0.46 & \\
\hline
\end{tabular}

$[24,25]$, pregnancy-induced hypertension, and LBW deliveries [26,27]. However, previous studies did not show any significant difference between birth weight in mothers with zinc deficiency [21], and birth weight was not correlated with maternal blood levels of zinc [20]. Badakhsh et al. [22] observed no association between LBW deliveries and low maternal zinc status. Likewise, recently, Gebremedhin et al. found no effect of prenatal zinc deficiency on newborn birth weight [28].

In the current study, as well as in a previous report, LBW newborns had higher cord zinc levels than their mothers [29]. However, Srivastava et al. [30] reported that maternal zinc levels are higher than cord zinc levels. The growing fetus is likely to store zinc in an escalating manner as gestational age advances [31]. There might be an active mechanism for transporting zinc across the placenta from the maternal side toward the fetus [32]. A clinical trial of pregnant women who were supplemented daily with $25 \mathrm{mg}$ of zinc showed a positive outcome in terms of birth weight and head circumference compared with the placebo group [33]. Maternal zinc deficiency in late pregnancy could be a determinant for newborn birth weight [34]. Recently, a study reported that LBW neonates with zinc deficiency are prone to lose more zinc in their early infancy [35].

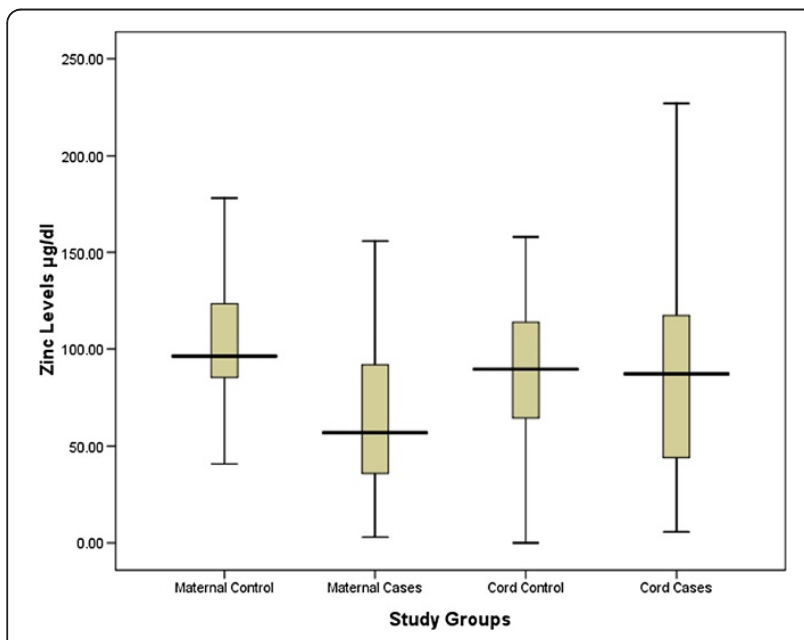

Figure 1 Maternal and cord levels of zinc in LBW cases and controls in Medani Hospital, Sudan.

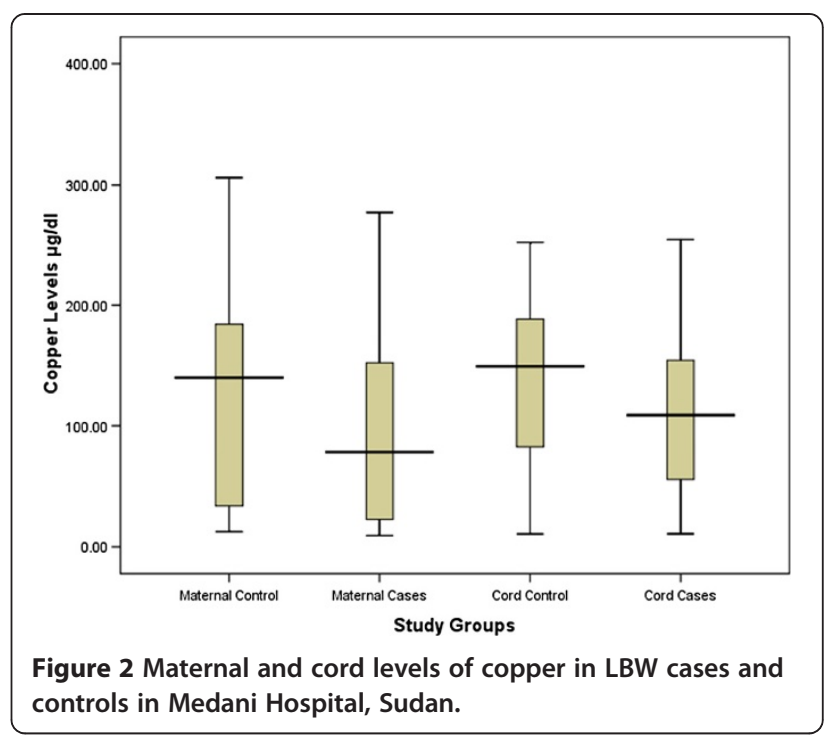

In the current study, significantly lower copper levels were observed in maternal and cord serum in LBW cases than in controls. During pregnancy, maternal copper increases as gestational age advances. This finding could be explained by an increase in synthesis of ceruloplasmin, a copper binding protein, in response to high levels of estrogen during pregnancy [36]. This ensures the availability of copper, as fetal and maternal demand increases [37]. A growing body of evidence has linked low maternal copper levels and LBW [13,37]. Copper deficiency during the prenatal, and even the early postnatal periods, can lead to defective energy production, altered bone structure, dysgenesis of blood vessels, and delayed lung development. Unfortunately, these changes might not subside, even with copper supplementation to deficient neonates [37].

In our study, in the case and control groups, copper levels were higher in cord blood than in maternal blood. This finding could be the cause of intrauterine growth restriction, as reported recently [38]. Copper concentrations in maternal and cord blood in cases and the control group were higher than zinc concentrations. High copper concentrations lead to competition with zinc for metallothionein binding sites, and thus decrease zinc availability [39]. In this study, there was a significant,

Table 3 Correlations among zinc, copper, and birth weight

\begin{tabular}{|c|c|c|c|c|c|c|c|c|}
\hline \multirow[t]{2}{*}{ Variables } & \multicolumn{2}{|c|}{$\begin{array}{l}\text { Maternal } \\
\text { zinc }\end{array}$} & \multicolumn{2}{|c|}{$\begin{array}{c}\text { Maternal } \\
\text { copper }\end{array}$} & \multicolumn{2}{|c|}{ Cord zinc } & \multicolumn{2}{|c|}{$\begin{array}{l}\text { Cord } \\
\text { copper }\end{array}$} \\
\hline & $r$ & $P$ & $r$ & $P$ & $r$ & $P$ & $r$ & $P$ \\
\hline Birth weight & 0.27 & 0.005 & 0.19 & 0.05 & 0.35 & 0.01 & 0.1 & 0.23 \\
\hline Maternal zinc & & & 0.39 & $<0.001$ & 0.29 & 0.003 & 0.13 & 0.16 \\
\hline Maternal copper & 0.39 & $<0.001$ & & & 0.18 & 0.07 & 0.04 & 0.63 \\
\hline Cord zinc & 0.29 & 0.003 & & & & & 0.004 & 0.96 \\
\hline
\end{tabular}


strong, positive correlation between birth weight and maternal and cord zinc concentrations, as found in a previous study [40]. A short inter-pregnancy interval is a risk factor for developing LBW [41-43]. Nevertheless, this factor was not significant in our study.

Maternal anemia is a contributing factor for LBW deliveries [2]. Zinc deficiency has been identified as a risk factor for maternal anemia [44]. Serum copper is not a predictor for maternal anemia, but significant copper deficiency has been observed in pregnant women with anemia [19]. Moreover, in non-pregnant adolescents, there is a positive correlation between hemoglobin levels and serum zinc and copper levels [45]. Deficiency in zinc and copper, and anemia might be interacting factors in the etiology of LBW because all of them can be involved maternal malnutrition.

This study has several limitations. First, the dietary content of zinc and copper was not quantified in this study. Second, measuring serum copper levels is less sensitive for detecting marginal copper deficiency, and this is similar for serum zinc levels. Third, this study was not designed to assess the differences in concentration of these elements in different trimesters. Therefore, further studies are required to determine these issues.

\section{Competing interests}

The authors declare that they have no competing interests.

\section{Authors' contributions}

RMA, HZH, NIA, and SZH carried out the study and participated in the statistical analysis and procedures. IA and EME coordinated and participated in the design of the study, statistical analysis, and drafting of the manuscript. All the authors read and approved the final version.

\section{Acknowledgements}

The authors are grateful to the women who participated in the study, and the entire staff of Wad Medani Hospital. Authors received no funding for this work

\section{Author details}

${ }^{1}$ Sudan Academy of Science, Khartoum, Sudan. ${ }^{2}$ Faculty of Medicine, Al-Neelain University, P.O. Box 12702, Khartoum, Sudan. ${ }^{3}$ Faculty of Medicine, University of Gezira, Wad Medani, Sudan. ${ }^{4}$ Sudan Atomic Energy Commission, Khartoum, Sudan. ${ }^{5}$ Faculty of Medicine, University of Khartoum, P.O. Box 102, Khartoum, Sudan.

Received: 28 October 2013 Accepted: 16 June 2014

Published: 24 June 2014

\section{References}

1. UNICEF, WHO: Low Birth weight: Country, Regional and Global estimates 2004. New York: UNICEF; 2004

2. Elhassan EM, Abbaker AO, Haggaz AD, Abubaker MS, Adam I: Anaemia and low birth weight in Medani Hospital Sudan. BMC Res Notes 2010, 3:181.

3. Child Health Research Project. Special Report: Reducing Perinatal and Neonatal Mortality. Report of a Meeting. Baltimore, MD: Child Health Research Project; 1999.

4. Stein CE, Fall CH, Kumaran K, Osmond C, Cox V, Barker DJ: Fetal growth and coronary heart disease in south India. Lancet 1996, 348:1269-1273.

5. Curhan GC, Willett WC, Rimm EB, Spiegelman D, Ascherio AL, Stampfer MJ: Birth weight and adult hypertension, diabetes mellitus, and obesity in US men. Circulation 1996, 94:3246-3250.

6. Wilcox A: On the importance - and unimportance of birthweight. Int J Epidemiol 2001, 30:1233-1241.
7. Hassan AA, Abubaker MS, Radi EA, Adam I: Education, prenatal care, and poor perinatal outcome in Khartoum, Sudan. Int J Gynaecol Obstet 2009, 105:66-67.

8. Mertz W: The essential trace elements. Science 1981, 213:1332-1338.

9. DiSilvestro RA: Zinc in relation to diabetes and oxidative disease. J Nutr 2000, 130:1509S-1511S.

10. Petersen SV, Enghild JJ: Extracellular superoxide dismutase: structural and functional considerations of a protein shaped by two different disulfide bridge patterns. Biomed Pharmacother 2005, 59:175-182.

11. Vallee BL, Falchuk KH: The biochemical basis of zinc physiology. Physiol Rev 1993, 73:79-118.

12. Izquierdo Alvarez S, Castañón SG, Ruata ML, Aragüés EF, Terraz PB, Irazabal YG, González EG, Rodríguez BG: Updating of normal levels of copper, zinc and selenium in serum of pregnant women. J Trace Elem Med Biol 2007, 21:49-52.

13. Pathak $P$, Kapil U: Role of trace elements zinc, copper and magnesium during pregnancy and its outcome. Indian J Pediatr 2004, 71:1003-1005.

14. Rwebembera AA, Munubhi EK, Manji KP, Mpembeni R, Philip J: Relationship between infant birth weight $\leq 2000 \mathrm{~g}$ and maternal zinc levels at Muhimbili National Hospital, Dar Es Salaam, Tanzania. J Trop Pediatr 2006, 52:118-125.

15. Elizabeth $\mathrm{KE}$, Krishnan $\mathrm{V}$, Vijayakumar $\mathrm{T}$ : Umbilical cord blood nutrients in low birth weight babies in relation to birth weight and gestational age. Indian J Med Res 2008, 128:128-133.

16. Adam I, Babiker S, Mohmmed AA, Salih MM, Prins MH, Zaki ZM: Low body mass index, anaemia and poor perinatal outcome in a rural hospital in eastern Sudan. J Trop Pediatr 2008, 54:202-204.

17. Haggaz AD, Radi EA, Adam I: Anaemia and low birth weight in western Sudan. Trans R Soc Trop Med Hyg 2010, 104:234-236.

18. Ali AA, Rayis DA, Abdallah TM, Elbashir Ml, Adam I: Severe anaemia is associated with a higher risk for preeclampsia and poor perinatal outcomes in Kassala hospital, eastern Sudan. BMC Res Notes 2011, 4:311.

19. Bushra M, Elhassan EM, Ali NI, Osman E, Bakheit KH, Adam II: Anaemia, zinc and copper deficiencies among pregnant women in central Sudan. Biol Trace Elem Res 2010, 137:255-261.

20. Al-Saleh $\mathrm{E}$, Nandakumaran $\mathrm{M}, \mathrm{Al}$-Shammari $\mathrm{M}, \mathrm{Al}$-Falah $\mathrm{F}, \mathrm{Al}$-Harouny $\mathrm{A}$ : Assessment of maternal-fetal status of some essential trace elements in pregnant women in late gestation: relationship with birth weight and placental weight. J Matern Fetal Neonatal Med 2004, 16:9-14.

21. Akman I, Arioglu P, Koroglu OA, Sakalli M, Ozek E, Topuzoglu A, Eren S, Bereket A: Maternal zinc and cord blood zinc, insulin-like growth factor-1, and insulin-like growth factor binding protein-3 levels in small-forgestational-age newborns. Clin Exp Obstet Gynecol 2006, 33:238-240.

22. Badakhsh MH, Khamseh ME, Seifoddin M, Kashanian M, Malek M, Shafiee G, Baradaran HR: Impact of maternal zinc status on fetal growth in an Iranian pregnant population. Gynecol Endocrinol 2011, 27:1074-1076.

23. World Bank Database. http://data.worldbank.org/country/sudan.

24. Simmer K, Thompson RPH: Maternal zinc and intrauterine growth retardation. Clin Sci 1985, 68:395-399.

25. Uriu-Adams JY, Keen CL: Zinc and reproduction: effects of zinc deficiency on prenatal and early postnatal development. Birth Defects Res B Dev Reprod Toxicol 2010, 89:313-325.

26. Jameson S: Zinc status in pregnancy. The effect of zinc therapy on perinatal mortality, prematurity and placental ablation. Ann NY Acad Sci 1993, 678:178-192.

27. Kirksey A, Wachs TD, Yunis F, Srinath U, Rahmanifar A, McCabe GP, Galal OM, Harrison GG, Jerome NW: Relation of maternal zinc nutriture to pregnancy outcome and infant development in an Egyptian village. Am J Clin Nutr 1994, 60:782-792.

28. Gebremedhin S, Enquselassie F, Umeta M: Independent and joint effects of prenatal Zinc and Vitamin A Deficiencies on birthweight in rural Sidama, SouthernEthiopia: prospective cohort study. PLoS One 2012, 7:e50213.

29. Iqbal AS, Shahidullah M, Islam MN, Akhter S, Banu S: Serum zinc and copper levels in the maternal blood and cord blood of neonates. Indian $J$ Pediatr 2001, 68:523-526.

30. Srivastava S, Mehrotra PK, Srivastava SP, Siddiqui MK: Some essential elements in maternal and cord blood in relation to birth weight and gestational age of the baby. Biol Trace Elem Res 2002, 86:97-105.

31. Zimmerman AW, Dunham BS, Nochimson DJ, Kaplan BM, Clive JM, Kunkel SL: Zinc transport in pregnancy. Am J Obstet Gynecol 1984, 149:523-529. 
32. Rossipal E, Krachler M, Li F, Micetic-Turk D: Investigation of the transport of trace elements across barriers in humans: studies of placental and mammary transfer. Acta Paediatr 2000, 89(10):1190-1195.

33. Goldenberg RL, Tamura T, Neggers Y, Copper RL, Johnston KE, DuBard MB, Hauth JC: The effect of zinc supplementation on pregnancy outcome. JAMA 1995, 274:463-468.

34. Neggers YH, Cutter GR, Alvarez JO, Goldenberg RL, Acton R, Go RC, Roseman JM: The relationship between maternal serum zinc levels during pregnancy and birth weight. Early Hum Dev 1991, 25:75-85.

35. Agarwal R, Virmani D, Jaipal M, Gupta S, Sankar MJ, Bhatia S, Agarwal A, Devgan V, Deorari A, Paul VK, Toteja GS: Investigators of the LBW Micronutrient Study Group Poor zinc status in early infancy among both low and normal birth weight infants and their mothers in Delhi. Neonatology 2013, 103(1):54-59.

36. Schenker JG, Jungreis E, Polishuk WZ: Serum copper level in normal and pathological pregnancies. Am J Obstet Gynecol 1969, 105:933-937.

37. Uriu-Adams JY, Scherr RE, Lanoue L, Keen CL: Influence of copper on early development: prenatal and postnatal considerations. Biofactors 2010, 36:136-152.

38. Ozdemir U, Gulturk S, Aker A, Guvenal T, Imir G, Erselcan T: Correlation between birth weight, leptin, zinc and copper levels in maternal and cord blood. J Physiol Biochem 2007, 63:121-128.

39. Bremner I: Interactions between metallothionein and trace elements. Prog Food Nutr Sci 1987, 11:1-37.

40. Bahl L, Chaudhuri LS, Pathak RM: Study of serum zinc in neonates and their mothers in Shimla hills (Himachal Pradesh). Indian J Pediatr 1994, 61:571-575.

41. Ugboma HA, Onyearugha CN: Low birthweight delivery: prevalence and associated factors as seen at a tertiary health facility. Niger I Clin Pract 2013, 16(2):184-187.

42. Mbazor OJ, Umeora OU: Incidence and risk factors for low birth weight among term singletons at the University of Benin Teaching Hospital, Benin City, Nigeria. Niger J Clin Pract 2007, 10:95-99.

43. Salihu HM, August EM, Mbah AK, De Cuba RJ 2nd, Alio AP, Rowland-Mishkit $\checkmark$, Berry EL: The impact of birth spacing on subsequent feto-infant outcomes among community enrollees of a federal healthy start project. J Community Health 2012, 37(1):137-142.

44. Mohamed AA, Ali AA, Ali NI, Abusalama EH, Elbashir Ml, Adam I: Zinc, parity, infection, and severe anaemia among pregnant women in Kassla, eastern Sudan. Biol Trace Elem Res 2011, 140(3):284-290.

45. Abdelrahim II, Mahgoub HM, Mohamed AA, Ali NI, Elbashir MI, Adam I: Anaemia, folate, zinc and copper deficiencies among adolescent schoolgirls in eastern Sudan. Biol Trace Elem Res 2009, 132(1-3):60-66.

\section{Submit your next manuscript to BioMed Central and take full advantage of:}

- Convenient online submission

- Thorough peer review

- No space constraints or color figure charges

- Immediate publication on acceptance

- Inclusion in PubMed, CAS, Scopus and Google Scholar

- Research which is freely available for redistribution 